\title{
Effects of black seed (Nigella sativa), ginger (Zingiber officinale) and cone flower (Echinacea angustifolia) on the immune system of rainbow trout, Oncorhynchus mykiss
}

\author{
[Efeitos de semente preta (Nigella sativa), gengibre (Zingiber officinale) \\ e Flor-de-cone (Echinacea angustifolia) no sistema imunológico \\ de truta arco-íris, Oncorhynchus mykiss] \\ F. Fadeifard ${ }^{1}$, M. Raissy ${ }^{1}$, M. Jafarian ${ }^{1}$, H.Rouhi Boroujeni ${ }^{2}$, M. Rahimi ${ }^{1}$, M. Faghani ${ }^{3}$ \\ ${ }^{1}$ Faculty of Veterinary Medicine, Shahrekord Branch, Islamic Azad University, Shahrekord, Iran \\ ${ }^{2}$ Member of Student Research Committee, Medical Plants Research Center, Shahrekord \\ University of Medical Sciences, Shahrekord, Iran \\ ${ }^{3}$ Faculty of Agriculture, Shahrekord Branch, Islamic Azad University, Shahrekord, Iran
}

\begin{abstract}
This study was carried out to evaluate the effects of dietary essential oils of ginger (Zingiber officinale), black seed (Nigella sativa) and cone flower (Echinacea angustifolia) on the immune system of cultured rainbow trout, Oncorhynchus mykiss.A total of 360 fish were divided into 4 groups and 3 replicates each containing 30 fish. The fish were fed for 21 days with $1 \%$ of the herbal essential oils and with unsupplemented diet as the control group. Haematological and immune parameters including serum lysozyme, number of phagocytic bacteria, Hb, $\mathrm{PCV}, \mathrm{MCV}, \mathrm{MCH}, \mathrm{MCHC}$, number of $\mathrm{RBC}$ and $\mathrm{WBC}$ were studied. Treatments recorded enhancement in immune parameters compared to the control group. Significantly higher serum lysozyme level and phagocytic germs were detected in the groups fed black seed, ginger and cone flower $(\mathrm{P}<0.05)$. However, no significant difference was found in $\mathrm{RBC}, \mathrm{Hb}, \mathrm{PCV}, \mathrm{MCV}, \mathrm{MCH}$ and $\mathrm{MCHC}$ of fish fed the diets containing essential oils and the control group $(\mathrm{P}>0.05)$. The results of this study demonstrated that essential oils might strengthen the non-specific immunity of rainbow trout.
\end{abstract}

Keywords: Nigella sativa, Zingiber officinale, Echinacea angustifolia, Immune response, Oncorhynchus mykiss

\section{RESUMO}

Avaliou-se a eficácia de uma dieta com semente preta (Nigella sativa), gengibre (Zingiber officinale) e Flor-de-cone (Echinacea angustifolia) sobre o sistema imunológico de truta arco-íris (Oncorhynchus mykiss) em cultivo. Um total de 360 peixes foram divididos em 4 grupos com 3 repetições cada, contendo 30 peixes. Os peixes foram alimentados por 21 dias com $1 \%$ de óleo essencial herbáceo e com dieta comercial não suplementada como controle. Parâmetros imunes e hematológicos incluindo soro lisozima, número de bactéria fagocítica, $\mathrm{Hb}, \mathrm{PCV}, \mathrm{MCV}, \mathrm{MCH}, \mathrm{MCHC}$, número de RBC e WBC foram estudados. Os tratamentos registraram a melhoria em parâmetros imunes comparados ao grupo de controle. Foram detectadas concentrações de lisozima no soro e germes fagocíticos significativamente altos em grupos que receberam semente preta, gengibre e Flor-de-cone $(\mathrm{P}<0.05)$. Porém, não foi encontrada diferença significativa em RBC, Hb, PCV, MCV, MCH e MCHC nos peixes alimentados com dietas contendo óleos essenciais e no grupo de controle $(\mathrm{P}>0.05)$. Os resultados deste estudo demonstraram que óleos essenciais podem aumentar a imunidade não específica da truta arco-íris.

Palavras-chave: Nigella sativa, Zingiber officinale, Echinacea angustifolia, resposta imune, Oncorhynchus mykiss

Recebido em 3 de junho de 2015

Aceito em 30 de dezembro de 2015

E-mail: fadaeifard@gmail.com 


\section{INTRODUCTION}

Rainbow trout is one of the most important cultivated fish and is the most common cultivated species in many countries including Iran. In recent years, weak management of fish farms and intensively cultured fisheries has caused severe infectious diseases among fishes. A number of approaches have been applied to control the pathogens in fish farms including disinfection, chemotherapy and using antibiotics (Raissy and Ansari, 2011). Nevertheless, there are numerous harmful effects related to the excessive usage of antibiotics and disinfectants, which include some effects of residues in fish meat on consumers' health and environmental hazards in waterborne applications. (SeungCheol et al., 2007).

On the other hand, the use of antimicrobials is not acceptable due to the potential for development of microbial resistance which may transfer to other bacterial species (Raissy and Ansari, 2011). Another approach to control and prevent the diseases in cultured fish is the application of immunostimulants to enhance the immune responses in a nonspecific manner (Seung-Cheol et al., 2007). Resistance to infectious diseases is increased by using immunostimulants which not only stimulate the acquired immune system but also enhance innate immune responses. (Dugenci et al., 2003).

The use of immunostimulants in aquaculture is considered a modern and suitable alternative to antibiotics.

These compounds are categorized into different classes such as bacteria or bacterial products, vaccines, immune system enhancing drugs, cytokines, lactoferin, lectins, animal and plant extracts (Mulero et al., 1998; Yin et al., 2006). These substances have been found to enhance non-specific immune responses through different pathways such as affecting phagocytic cell activity, natural killer cell activity, lysozyme levels, complement levels and immunoglobulin M (IgM) levels (Dugenci et al., 2003). Some of immune enhancers have been reported to confer a degree of protection against important fish pathogens such as Vibrio anguillarum, Aeromonas salmonicida or Yersinia ruckeri (Mulero et al., 1998; Baulny, 1996). However, some of these compounds could not be used because of some limitations such as high cost, limited effectiveness, low absorption and accumulation in fish body (Dugenci et al., 2003).

Various medicinal plants and their derivatives are known for their immunostimulating characteristics. Nigella sativa, Zingiber officinale and Echinacea angustifolia are known to have many therapeutic properties in traditional medicine (Salem and Hossain, 2000). Their antibacterial, anthelmentic, antidiabetic, antioxidant and anti-inflammatory effects in animals have been investigated (Kanter et al., 2003; Alishahi and Mesbah, 2012; Diab et al., 2008; John et al., 2007), however, the effect of these plants on the immune system of rainbow trout is not well studied.

Therefore, the aim of this work was to study the effects of essential oil of Nigella sativa, Zingiber officinale and Echinacea angustifolia added to the diet on the hematological and immune parameters of rainbow trout.

\section{MATERIALS AND METHODS}

A total of 360 healthy rainbow trout with average weight of $90 \pm 5 \mathrm{~g}$ were obtained from a local fish farm in Chaharmahal va Bakhtiari Province, Iran and acclimatized in aerated ponds for two weeks (water temperature: $12.8 \pm 1^{\circ} \mathrm{C}$, DO: $7.6 \pm 0.2 \mathrm{mg}$ $\mathrm{L}^{-1}, \mathrm{pH}: 7.3 \pm 0.3$, Ammonia: $0.002 \pm 0.0004 \mathrm{mg} \mathrm{L}^{-}$ ${ }^{1}$, Nitrite: $0.01 \pm 0.005 \mathrm{mg} \mathrm{L}^{-1}$ ). The fish were then randomly divided into four groups, each comprising of 90 fish (30 per replicate). Fish were fed a commercial diet three times daily for a period of 21 days. The essential oils were added to the experimental diet at a level of $1 \mathrm{~g} / 100 \mathrm{~g}$ of diet. At the end of the study, fish were anaesthetized with clove oil $\left(150 \mathrm{mg} \mathrm{L}^{-1}\right)$ and blood samples were collected by caudal vein puncture. Half of each blood sample was transferred to a sterile vial containing heparin and kept at $4{ }^{\circ} \mathrm{C}$ for hematological analysis. Another half allowed to clot for $2 \mathrm{~h}$ at $4^{\circ} \mathrm{C}$. The serum was separated after centrifuging at 2000 $\mathrm{rpm}$ for $10 \mathrm{~min}$ and stored at $-20^{\circ} \mathrm{C}$.

Hematological parameters were determined according to routine laboratory techniques. The red blood cells $\left(\mathrm{RBC} \times 10^{6} \mu \mathrm{l}\right)$ and total leukocyte count $\left(\mathrm{WBC} \times 10^{4} \mu \mathrm{l}\right)$ were determined manually by haemocytometer with Hayem solution as diluent. The haemoglobin level ( $\mathrm{g} d \mathrm{~L}-1)$ was determined with a spectrophotometer at $540 \mathrm{~nm}$ 
by the cyamethaemoglobin method. Hematocrit (\%) was determined by using microhaematocrit heparinized capillary tubes of $75 \mu 1$ volume and microhaematocrit centrifuge at $7000 \mathrm{~g}$ for $10 \mathrm{~min}$ (Blaxhall and Daisley, 1973).

Differential counting of white blood cells was performed after preparation of blood smear slides that stained with Wright-Giemsa. The Percentage of each WBC type was computed in at least 100 white blood cells under a light microscope (Hoseinifar et al., 2010). The red blood cell indices including the mean values of cell haemoglobin $(\mathrm{MCH}, \mathrm{pg})$, cell hemoglobin concentration (MCHC, \%), and cell volume (MCV, fL) were calculated according to Wintrobe (1993).

Phagocytosis activity of white blood cells was determined by spectrophotometer according to the method of Seeley et al. (1990). This method is based on the measurement of congo redstained yeast cells (Saccharomyces cerevisiae) that have been phagocytosed by WBC. Yeast cells were stained by congo red and autoclaved, then a suspension of yeast: leukocyte with a 40:1 ratio was prepared. In the next stage, $250 \mu 1$ of the WBC solution was added to $500 \mu 1$ of the suspension and incubated for $60 \mathrm{~min}$ at room temperature. One $\mathrm{ml}$ of percoll (1.055) was injected into the bottom of each micro tube after adding $1 \mathrm{ml}$ of ice-cold HBSS. In order to separate leukocytes from yeast, samples were centrifuged at $850 \mathrm{rpm}$ for $5 \mathrm{~min}$. Then Leukocytes were collected and washed twice in HBSS for two times. Subsequently, the collected leukocytes were incubated at $37^{\circ} \mathrm{C}$ overnight after re-suspending in $1 \mathrm{ml}$ trypsin-EDTA solution $(5.0 \mathrm{~g} / \mathrm{l}$ trypsin and $2.0 \mathrm{~g} / \mathrm{l}$ EDTA, Sigma). Finally, the samples' absorbance was measured at 510nm using trypsin-EDTA as a blank.

Turbidimetric method described by Ellis et al. (1990) was used to measure lysozyme activity of the obtained serum samples. Briefly, 250mL-1 of each serum sample was added to aliquots (1.75mL-1) of Micrococcus lysodeikticus (Sigma, USA) suspension (0.375mg mL-1, 0.05 M PBS, pH 6.2). Measurement of the samples' OD was carried out at $670 \mathrm{~nm}$ after 15 and $180 \mathrm{~s}$ by spectrophotometer (Eppendorf, Germany). One unit of lysozyme activity was defined as the amount of enzyme that caused a decrease in absorbance of 0.001 .

The results were analyzed by one-way analysis of variance (ANOVA). Tukey's test was used to compare values by SPSS 18.0 statistical software (SPSS Inc., USA). The differences were considered statistically significant when $\mathrm{P} \leq 0.05$.

\section{RESULTS}

The effects of the essential oils on blood cells, $\mathrm{Hb}, \mathrm{MCV}, \mathrm{MCH}, \mathrm{MCHC}$, hematocrit, serum lyzosyme and phagocytic activity are given in Tab. 1 and Tab. 2. According to the results, lysozyme level in the fish fed the essential oils were found to be significantly higher than the control group $(\mathrm{P}<0.05)$. The number of phagocytic germs in treatments were also significantly higher than the control group $(\mathrm{P}<0.05)$. Although leukocyte level in different groups was not significantly different, the percent of neutrophils and lymphocytes were found to be higher in the fish fed Nigella sativa diet comparing the control group $(\mathrm{P}<0.05)$. There was no significant difference in haematological parameters including $\mathrm{RBC}, \mathrm{Hb}, \mathrm{PCV}, \mathrm{MCV}$, $\mathrm{MCH}$ and $\mathrm{MCHC}$ of fish fed the diets containing essential oils and the control group $(\mathrm{P}>0.05)$.

Table 1. Immunological parameters in fish fed diets containing essential oils and control group

\begin{tabular}{lllllll}
\hline & $\begin{array}{l}\text { Lysozyme } \\
\text { (unit/ml) }\end{array}$ & $\begin{array}{l}\text { Lymphocyte } \\
(\%)\end{array}$ & $\begin{array}{l}\text { Neutrophil } \\
(\%)\end{array}$ & $\begin{array}{l}\text { Basophil } \\
(\%)\end{array}$ & $\begin{array}{l}\text { Eosinophil } \\
(\%)\end{array}$ & $\begin{array}{l}\text { Number of } \\
\text { phagocytic } \\
\text { germs }\end{array}$ \\
\hline $\begin{array}{l}\text { Nigella } \\
\text { sativa }\end{array}$ & $28.8 \pm 9.1 \mathrm{a}$ & $72.8 \pm 2.6 \mathrm{a}$ & $21.5 \pm 3.7 \mathrm{~b}$ & $0.5 \pm 0.02 \mathrm{a}$ & $1.6 \pm 0.5 \mathrm{a}$ & $17.6 \pm 5.1 \mathrm{a}$ \\
$\begin{array}{l}\text { Echinacea } \\
\text { angustifolia }\end{array}$ & $23.3 \pm 9.1 \mathrm{a}$ & $75 \pm 2.1 \mathrm{ab}$ & $17.5 \pm 1.8 \mathrm{a}$ & $0.6 \pm 0.5 \mathrm{a}$ & $1.8 \pm 0.5 \mathrm{~b}$ & $19.5 \pm 4.8 \mathrm{a}$ \\
$\begin{array}{l}\text { Zingiber } \\
\text { officinale }\end{array}$ & $28.6 \pm 7.6 \mathrm{a}$ & $75 \pm 2.9 \mathrm{ab}$ & $18.4 \pm 2.9 \mathrm{a}$ & $0.6 \pm 0.5 \mathrm{a}$ & $1.7 \pm 0.5 \mathrm{a}$ & $20.7 \pm 3.8 \mathrm{a}$ \\
$\begin{array}{l}\text { Control } \\
\text { Different letters indicate statistically significant differences for multiple comparisons within a parameter }(\mathrm{P}=0.05) .\end{array}$
\end{tabular}


Table 2. Hematological parameters in fish fed diets containing essential oils and control group

\begin{tabular}{llllllll} 
& $\begin{array}{l}\text { WBC } \\
\left(10^{3}\right)\end{array}$ & $\begin{array}{l}\mathrm{RBC} \\
\left(10^{6}\right)\end{array}$ & $\begin{array}{l}\mathrm{Hb} \\
(\mathrm{g} \mathrm{dL}-1)\end{array}$ & PCV $(\%)$ & MCV (fL) & $\begin{array}{l}\text { MCH } \\
(\mathrm{pg})\end{array}$ & $\begin{array}{l}\text { MCHC } \\
(\mathrm{g} / \mathrm{dL})\end{array}$ \\
\hline $\begin{array}{l}\text { Nigella } \\
\text { sativa }\end{array}$ & $16.2 \pm 0.1 \mathrm{a}$ & $3.5 \pm 0.4 \mathrm{a}$ & $10.3 \pm 0.4 \mathrm{a}$ & $41.1 \pm 5.4 \mathrm{a}$ & $115.1 \pm 9.2 \mathrm{a}$ & $29.2 \pm 3.4 \mathrm{a}$ & $25.4 \pm 2.8 \mathrm{a}$ \\
$\begin{array}{l}\text { Echinacea } \\
\text { angustifolia }\end{array}$ & $17.1 \pm 0.2 \mathrm{a}$ & $3.7 \pm 0.2 \mathrm{a}$ & $9.6 \pm 0.5 \mathrm{a}$ & $41.8 \pm 2.9 \mathrm{a}$ & $114.2 \pm 12.5 \mathrm{a}$ & $28.2 \pm 4.3 \mathrm{a}$ & $24.7 \pm 3.3 \mathrm{a}$ \\
$\begin{array}{l}\text { Zingiber } \\
\text { officinale }\end{array}$ & $18.6 \pm 3.2 \mathrm{a}$ & $3.3 \pm 0.3 \mathrm{a}$ & $9.4 \pm 0.6 \mathrm{a}$ & $39.7 \pm 4.4 \mathrm{a}$ & $117.9 \pm 20.3 \mathrm{a}$ & $29.3 \pm 3.1 \mathrm{a}$ & $24.9 \pm 4.1 \mathrm{a}$ \\
\begin{tabular}{l} 
Control \\
\hline
\end{tabular} & $16.3 \pm 9.5 \mathrm{a}$ & $3.3 \pm 0.4 \mathrm{a}$ & $10.03 \pm 0.7 \mathrm{a}$ & $39.3 \pm 4.5 \mathrm{a}$ & $113.6 \pm 22.08 \mathrm{a}$ & $28.2 \pm 5.2 \mathrm{a}$ & $24.1 \pm 4.3 \mathrm{a}$ \\
\hline
\end{tabular}

Different letters indicate statistically significant differences for multiple comparisons within a parameter $(\mathrm{P}=0.05)$.

\section{DISCUSSION}

The application of medicinal plants and their derivates as immunostimulants in fish culture is an effective and safe method to enhance the immune responses against pathogens during periods of stress, such as intensive farming culture, grading, vaccination and reproduction. Hematological parameters provide an index of the physiological status of fish. The number of red blood cells, leukocytes, hematocrit and hemoglobin are from the tests that could be performed in fish farms to evaluate the health status of the stock. In this study both hematological and immunological parameters of rainbow trout fed the diet containing Nigella sativa, Zingiber officinale and Echinacea angustifolia were studied.

The results of this study revealed that feeding rainbow trout with $1 \%$ dose of black seed, ginger and cone flower for 21 days stimulates some non-specific immune parameters which is in agreement with the results of other studies (Dugenci et al., 2003; Altinterim and Dorucu, 2013; Awad et al., 2013; Haghighi and Sharif Rohani, 2013). Altinterim and Dorucu (2013) reported the Immunostimulatory effects of black seed administered by different methods in rainbow trout. According to their results, smearing the extracts up the lateral line of fish is the most efficient method to enhance immune parameters comparing to ip-injection and dietary supplementation as the highest levels of red and white blood cells, PCV and NBT were observed in directly exposed fish.

In the current study, neutrophil population in fish which received essential oils were higher than the control group. Neutrophils in the black seed group were found to be statistically higher than other groups $(\mathrm{P} \leq 0.05)$. Neutrophils play a critical role in non-specific defense mechanisms in fish. These cells increase during infectious diseases and directly attack microorganisms and other foreign toxic materials. It seems that an increase in neutrophil population is a similar pathway to some medicinal plants to enhance non-specific immune system as the use of nettle has resulted in a significant increase in the number of neutrophils after 4 weeks. Haghighi and Sharif Rouhani (2013) reported an increase in neutrophil population in rainbow trout fed ginger compared to the control group. Awad and Austin (2010) also reported an enhancement in rainbow trout neutrophil population after feeding with lupine, mango and nettle. Similar results have been reported by Binaii et al. (2014). Despite the increase of neutrophils, leukocyte levels in fish fed the herbal essential oil added diet were not significantly different compared to the control group. Statistically significant differences $(\mathrm{P} \leq 0.05)$ between phagocytic activity of blood leukocytes in experimental groups and the control group confirming previous findings. A variety of medicinal plants are known to stimulate phagocyte cells including ginger, garlic, curcumin and turmeric (Dugenci et al., 2003). However, no previous study on the effects of ginger, black seed and cone flower on phagocytic activity of leukocytes in rainbow trout was found. The increase in the number of neutrophils and also the phagocytosis ability will result in significant enhancement of the immune system of fish.

Serum lysozyme is an important component in the immune system of fish, lysing peptidoglycan layer of Gram-positive and some Gram-negative bacteria. It also has an important role in the activation of phagocyte cells by acting as an opsonin (Bilen et al., 2011). 
The results of this study revealed a significant increase in serum lysozyme levels in fish fed the diet containing the essential oils compared to the control group $(\mathrm{P}<0.05)$. Similar results were reported by Awad et al. (2013) as feeding rainbow trout with black seed oil for two weeks led to significant enhancement in serum lysozyme. The lysozyme level was found to be increased with dietary Cotinus coggyria and Zingiber officinal in rainbow trout (Bilen et al., 2011).

The increase of hemoglobin and hematocrit levels have been reported in rats fed black seed (Zaoui et al., 2002). In this study, no statistical differences were found in haematological parameters including $\mathrm{RBC}, \mathrm{Hb}, \mathrm{MCV}, \mathrm{MCH}$, MCHC and Hct levels between fish fed the essential oil supplemented diet and the control group ( $\mathrm{P}>0.05)$.

\section{CONCLUSION}

The results of this study indicate that Nigella sativa, Zingiber officinale and Echinacea angustifolia essential oils are able to enhance some non-specific immune parameters in rainbow trout. However, further studies should be done to determine the optimal dose, effects in combination with other immunostimulants and treatment duration. In general, this study suggests that herbal essential oils can be applied to increase the immune system of rainbow trout.

\section{REFERENCES}

ALISHAHI. M.; MESBAH, M. Effects of Viscum album and Nigella sativa extracts on survival rate, growth factors and resistance to Aeromonas hydrophila infection in gold fish (Carassius auratus). J. Vet. Res., v.67, p.285290, 2012.

ALTINTERIM, B.; DORUCU, M. The effects of Nigella sativa oil on the immune system of rainbow trout with different application methods. J. Fish. Sci., v.7, p.209-215, 2013.

AWAD, E.; AUSTIN, B. Use of lupin, Lupinus perennis, mango, Mangifera indica, and stinging nettle, Urtica dioica, as feed additives to prevent Aeromonas hydrophila infection in rainbow trout, Oncorhynchus mykiss (Walbaum). J. Fish Dis., v.33, p.413-420, 2010.
AWAD, E.; AUSTIN, D.; LYNDON, A.R. Effect of black seed oil (Nigella sativa) and nettle extract (Quercetin) on enhancement of immunity in rainbow trout, Oncorhynchus mykiss (Walbaum). Aquaculture, v.388-391, p.193-197, 2013.

BAULNY, M.; QUENTEL, C.; FOURNIER, V. et al. Effect of long-term oral administration of $\beta$-glucan as an immunostimulant or an adjuvant on some non-specific parameters of the immune response of turbot Scophthalmus maximus. Dis. Aquat. Org., v.26, p.139-147, 1996.

BILEN, S.; BULUT, M.; BILEN, M.A. Immunostimulant effects of Cotinus coggyria on rainbow trout (Oncorhynchus mykiss). Fish Shellfish Immunol., v.30, p.451-455, 2011.

BINAII, M.; GHIASI, M.; VAHIDFARABI, S.M. et al. Biochemical and hematoimmunological parameters in juvenile beluga (Huso huso) following the diet supplemented with nettle (Urtica dioica). Fish Shellfish Immunol., v.36, p.46-51, 2014.

BLAXHALL, P.C.; DAISLEY, W. Routine haematological methods for use with fish blood. J. Fish Biol., v.5, p.771-781, 1973.

DIAB, A.S.; ALY, S.M.; JOHN, G. et al. Effect of garlic, black seed and Biogen as immunostimulants on the growth and survival of Nile tilapia, Oreochromis niloticus (Teleostei: Cichlidae) and their response to artificial infection with Pseudomonas fluorescens. Afr. J. Aquat. Sci., v. 33, p.63-68, 2008.

DUGENCI, S.K.; ARDA, N.; CANDAN, A. Some medicinal plants as immunostimulant for fish. J. Ethnopharmacol., v.88, p.99-106, 2003.

ELLIS, A.E. Lysozyme assay. In: STOLEN, J.S.; FLETCHER, T.C.; ANDERSON, D.P. et al. Techniques in fish immunology. New Jersey: SOS Publications, 1990. p.101-103.

HAGHIGHI, M.; SHARIF ROHANI, M. The effects of powdered ginger (Zingiber officinale) on the haematological and immunological parameters of rainbow trout Oncorhynchus mykiss. J. Med. Plant Herbal Ther. Res., v.1, p.7-12, 2013. 
HOSEINIFAR, S.H.; MIRVAGHEFI, A.; MOJAZIAMIRI, B. et al. The effects of oligofructose on growth performance, survival and autochthonous intestinal microbiota of beluga (Husohuso) juveniles. Aquac. Nutr., v.17, p.498-504, 2010.

JOHN, G.; MESALHY, S.; REZK, M. Effect of some immunostimulants as feed additives on the survival and growth performance of Nile tilapia, Oreochromis niloticusand their response to artificial infection. Egypt J. Aquat. Biol. Fish., v.11, p.1299-308, 2007.

KANTER, M.; MERAL, I.; YENER, Z. Partial regeneration/proliferation of the beta-cells in the islets of langerhans by Nigella sativa L. in streptozotocin induced diabetic rats. Tohoku J. Exp. Med., v.201, p.213-219, 2003.

MULERO, V.; ESTEBAN, M.A.; MUNOZ, J. et al. Dietary intake of levamisole enhances the immune response and disease resistance of the marine teleost gilthead sea bream (Sparus aurata L.). Fish Shellfish Immunol., v.8, p.49-62, 1998,

RAISSY, M.; ANSARI, M. Antibiotic susceptibility of Lactococcus garvieae isolated from rainbow trout (Oncorhynchus mykiss). Afr. J. Biotechnol., v.10, p.1473-1476, 2011.
SALEM, M.L.; HOSSAIN, M.S. Protective effect of black seed oil from Nigella sativa against Murine cytomegalovirus infection. Int. J. Immunopharmacol., v.22, p.729-740, 2000.

SEELEY, K.R.; GILLESPIE, P.D.; WEEKS, B.A. A simple technique for the rapid spectrophotometric deterination of phagocytosis by fish macrophages. Marine Env. Res., v.30, p.37-41, 1990.

SEUNG-CHEOL, J.I.; TAKAOKA, O.; JEONG, G.S. et al. Dietary medicinal herbs improve growth and non-specific immunity of red sea bream Pagrus major. Fish Sci., v.73, p.63-69, 2007.

WINTROBE, M.M. Variation in size and haemoglobin concentration of erythrocyte in the blood of various vertebrates. Folia Haematol., v.51, p.32-49, 1933.

YIN, G.; JENEY, G.; RACH, T. Effect of two Chinese herbs (Astragalus radix and Scutella riaradix) on non-specific immune response of tilapia Oreochromis niloticus. Aquaculture, v.253, p.39-47, 2006.

ZAOUI, A.; CHERRAH, Y.; MAHASSINI, N. et al. Acute and chronic toxicity of Nigella sativa fixed oil. Int. J. Phytother. Phytopharmacol., v.9, p.69-74, 2002. 